\title{
EMPIRICAL STUDIES OF THE EFFECT OF OPERATIONAL COSTS AND OPERATING INCOME, FINANCING TO DEPOSIT RATIO AGAINST RETURN ON ASSET WITH NON-PERFORMING FINANCING AS INTERVENING VARIABLES IN SHARIA BANK INDONESIA 2013-2020
}

\author{
Rini Apriyanti, ${ }^{*}$ Asmak Ab Rahman ${ }^{2}$, Shinta Maharani ${ }^{3}$ \\ ${ }^{13}$ The State of Islamic Studies Ponorogo, Indonesia \\ ${ }^{2}$ Department of Sharia and Economics, Academy of Islamic Studies, University of Malaya, \\ Malaysia \\ Email: riniapriyanti49@gmail.com ${ }^{1}, \underline{\text { asmak@um.edu.my }}{ }^{2}, \underline{\text { maharani@ponorogo.ac.id }}^{3}$
}

\begin{abstract}
Return On Asset is a profitability ratio that can measure the company's ability to produce labs. In this study, the researchers found data on the quarterly financial reports of Bank Syariah Indonesia that the FDR value increases. However, the ROA value and decreased, found the BOPO and NPF values decreased but were not accompanied by an increase in ROA. This study using a quantitative method with an associative approach. The type of data used is secondary data from the 2013 first-quarter financial statements - In the fourth quarter of 2020, data is taken from the Bank Syariah Indonesia website. Data analysis using classical assumption test, simple linear regression analysis, linear regression analysis multiple, hypothesis testing, and path analysis. The results showed that NPF could mediate between BOPO and ROA. NPF can mediate between FDR and ROA. The cause of the decrease in ROA is caused because the BOPO value is still relatively high due to Sharia Bank Indonesia's performance less efficient and have the FDR value in several quarters exceed the maximum limit. So it indicates that the bank is less efficient in the distribution of financing and has an NPF value that exceeds the limit set by Bank Indonesia in several quarters. The solution is to make BOPO efficient. Indonesian Sharia Banks must pay attention to operational efficiency by paying attention to costs incurred with revenue received. A low BOPO will significantly affect the level of profit Islamic banks to improve the quality of ROA. Furthermore, more cost-effectiveness further increases the income so that the profit obtained is higher. Next, Bank Syariah Indonesia must use the number of funds in the banking sector to channel financing so that the risk of financing is getting higher reduced.
\end{abstract}

Keywords: Return on Assets, Non-Performing Finance, Bank Syariah Indonesia

\section{INTRODUCTION}

Islamic banks are banks that carry out their business activities based on Sharia principles and according to their types, Sharia Commercial Banks and Financing Banks Sharia People(Wangsawidjaja Z, 2012). The existence of Islamic banks in Indonesia has become a phenomenon in Indonesia amidst the ups and downs of the banking industry. 
With the situation and economic conditions Indonesia today is often shaken by inflation and various crises, banks Sharia can show good performance even though it is undeniably affected by changes in economic conditions(Armereo, 2015). However, amid a Covid-19 pandemic situation like this, the Islamic banking sector quite a lot of challenges. Amid the economic conditions hit by the Covid-19 pandemic, everyone business is experiencing a slowdown, and the Islamic banking industry is no exception. Restrictions of social and economic activities cause a decline in activities. These risks are faced in banking in general, especially in sharia banking. Risk of increased liquidity difficulties, decrease in financial assets, decrease in profitability and risk the growth of sharia banking is slowing down or even harmful(Tahliani, 2020). Given the crucial role of sharia in Indonesia, it needs to be improved the performance of sharia banks so that banks with sharia principles remain healthy and efficient. Profitability is the most appropriate indicator to measure the performance of a bank. The indicator which is often used to measure the performance of bank profitability is Return on Assets. Return on Asset is a ratio that shows the profit ratio (before tax) to the Asset. This ratio is used to assess a company's financial condition using a specific scale or a tool to assess whether the company owns all assets used to the maximum extent possible for profit(Tambunan, 2007). Several factors are used to measure the effectiveness of profitability or return on assets is operating costs and operating income, financing to deposit ratio, and non-performing financing(Sugiono \& Untung, 2016).

The first factor of BOPO is often called the efficiency ratio. Operational is a comparison between operating costs and operating income. The ratio of operational costs is used to measure the bank's efficiency and ability in carrying out operations. (Dendawijaya, 2005). The higher the BOPO, the operational activities become inefficient. If the activity is carried out efficiently, the profit will be more significant and ultimately improve financial performance(Mahardian, 2008). The second factor is the Financing Deposit Ratio, and this ratio is used to measure how much far the ability of the bank to repay customer financing withdrawals by relying on the source of funds provided as a source of liquidity(Dendawijaya, 2001). Financing Deposit Ratio (FDR) is a ratio to measure the composition of the amount of financing given compared to the number of public funds and own capital used(Kasmir, 2015). The third factor for NonPerforming Financing (NPF) is financing. The collectability category is included in the criteria for substandard financing, financing doubt, and financing stuck. (Dendawijaya, 
2005). The NPF ratio used by Islamic banks or credit ratios shows that the bank's ability to manage finance is problematic. So that the higher this ratio, the worse it will be the quality of bank credit which causes the number of non-performing financing to increase(Hariyani, 2010).

Table 1. The following is a table of developments in the value of OEOI, FDR and ROA, and NPF in Islamic Banks Indonesia in 2013-2020

\begin{tabular}{|c|c|c|c|c|c|}
\hline Year & QUARTERLY & $\begin{array}{c}\text { BOPO } \\
\text { X1 }\end{array}$ & $\begin{array}{c}\text { FDR } \\
\text { X2 }\end{array}$ & $\begin{array}{c}\text { ROA } \\
\mathbf{Y}\end{array}$ & $\begin{array}{c}\text { NPF } \\
\mathbf{Z}\end{array}$ \\
\hline \multirow[t]{4}{*}{2013} & March & 85.54 & 100.9 & 0.17 & 3.04 \\
\hline & June & 87.55 & 103.67 & 1.41 & 2.49 \\
\hline & September & 80.8 & 105.61 & 1.34 & 2.98 \\
\hline & December & 95.24 & 102.7 & 1.15 & 3.49 \\
\hline \multirow[t]{4}{*}{2014} & March & 92.43 & 102.13 & 0.46 & 4.04 \\
\hline & June & 99.84 & 95.14 & 0.03 & 4.38 \\
\hline & September & 97.35 & 94.85 & 0.2 & 4.79 \\
\hline & December & 99.14 & 93.9 & 0.08 & 4.6 \\
\hline \multirow[t]{4}{*}{2015} & March & 99.43 & 102.13 & 0.46 & 4.04 \\
\hline & June & 93.84 & 92.05 & 0.78 & 5.31 \\
\hline & September & 93.91 & 86.61 & 0.8 & 4.9 \\
\hline & December & 93.79 & 84.16 & 0.76 & 4.86 \\
\hline \multirow[t]{4}{*}{2016} & March & 90.7 & 82.73 & 0.99 & 4.84 \\
\hline & June & 90.41 & 87.92 & 1.03 & 4.87 \\
\hline & September & 90.99 & 83.98 & 0.98 & 5.22 \\
\hline & December & 91.33 & 81.42 & 0.95 & 4.57 \\
\hline \multirow[t]{4}{*}{2017} & March & 93.67 & 77.56 & 0.65 & 4.71 \\
\hline & June & 92.78 & 76.79 & 0.71 & 4.82 \\
\hline & September & 92.03 & 73.14 & 0.82 & 4.82 \\
\hline & December & 95.24 & 71.87 & 0.51 & 6.43 \\
\hline \multirow[t]{4}{*}{2018} & March & 90.75 & 68.1 & 0.86 & 4.92 \\
\hline & June & 89.92 & 77.78 & 0.92 & 5.13 \\
\hline & September & 91.49 & 76.40 & 0.77 & 5.3 \\
\hline & December & 95.32 & 75.49 & 0.43 & 6.73 \\
\hline \multirow[t]{4}{*}{2019} & March & 95.67 & 79.55 & 0.43 & 5.68 \\
\hline & June & 96.74 & 85.25 & 0.32 & 4.98 \\
\hline & September & 96.78 & 90.4 & 0.32 & 4.45 \\
\hline & December & 96.8 & 80.12 & 0.31 & 5.22 \\
\hline \multirow[t]{3}{*}{2020} & March & 90.18 & 92.10 & 1.00 & 2.35 \\
\hline & June & 89.93 & 91.01 & 0.90 & 3.99 \\
\hline & September & 90.39 & 82.65 & 0.84 & 3.35 \\
\hline
\end{tabular}




\begin{tabular}{cccccc}
\hline Year & QUARTERLY & BOPO & FDR & ROA & NPF \\
& & X1 & X2 & Y & Z \\
\hline & December & 91.01 & 80.99 & 0.81 & 3.24 \\
\hline
\end{tabular}

Source: Islamic Bank Indonesia Quarterly Financial Report March 2015 December 2020.

Based on Table 1, it can be seen that the ROA value of Islamic Bank Indonesia is low, thus indicating the financial performance of Islamic Bank Indonesia has not been efficient. If operational efficiency will be issued yields, it more significant profits. It causes profitability Islamic banks to decline, and a detailed review is needed to improve the situation. In the quarterly financial reports, it can be seen that the BOPO value at the Bank Sharia Indonesia is still high with an average of $89 \%$; this can be seen in several quarters that have a value of more than $90 \%$. In the 4th quarter of December 2015, the value of OEOI decreased by $0.12 \%$, and ROA decreased from the previous quarter to $0.04 \%$. In the second quarter of June 2020, the BOPO value decreased by $0.25 \%$, and the ROA value also decreased by $0.1 \%$. Based on these results, contrary to the existing theory states, if the ROA value is getting lower, it would be BOPO value is higher. The higher the BOPO, the more inefficient operational activities will be. If activities are carried out efficiently, the profit will be even more significant and, in the end, improve financial performance(Mahardian, 2008). Based on the quarterly financial reports, it can be seen that the FDR value is at Bank Syariah Indonesia has an average of $86 \%$, which means that the FDR value is good, it is just several deep quarters the FDR value exceeds the maximum limit of $100 \%$. In the 1st quarter of March 2019, the FDR value increased by $5.7 \%$, and the ROA value decreased by $0.11 \%$ based on the results.

The FDR contradicts the existing theory. If the FDR value increases, the ROA value in the Indonesian Sharia Bank will also go up. The greater the FDR value, the more whether a bank shows the financing provided by various banks to generate high profits and be balanced with capital owned by a bank(Septiani \& Lestari, 2016). The NPF value at Bank Syariah Indonesia is high in several quarters. The NPF value reached more than 5\%, with an average of $4.3 \%$. The high NPF value indicates that the amount of non-performing financing at Bank Syariah Indonesia is high, thus affecting the level of income of the bank itself. Based on financial statements quarterly, it can be seen that the NPF value in the 4th quarter of December 2016 experienced a decrease of $0.03 \%$ and a decrease in the ROA value of $0.65 \%$, and the NPF value in the 2nd quarter 
of June 2019 it decreased by $0.11 \%$ and the ROA value decreased by $0.7 \%$. The financial report data of Bank Syariah Indonesia is not under the existing relevant theory, which says that the higher it is NPF value (above 5\%) means the bank is not healthy. A high NPF lowers profits (ROA) to be received by the bank(Wangsawidjaja Z, 2012). The higher the NPF ratio, the worse the quality of bank credit, causes the number of problem loans to get bigger and causes losses. On the other hand, if the lower NPF, the bank's profit or profitability (ROA) will increase(Rosidah, 2017).

\section{LITERATURE REVIEW}

\section{Return On Asset}

One of the measuring tools for bank profitability is Return On Asset. This ratio represents Bank profitability performance measures are used to measure the effectiveness of the company in generating profits by utilizing the assets it has (Parenrengi \& Hendratni, 2018). Return on Asset is a ratio that compares profit (before tax) with total assets. This ratio is used to assess the financial condition of companies whether all assets are used to obtain the advantage(Tambunan, 2007).

\section{Operational Costs and Operating income}

The ratio of operating costs and operating income (BOPO) is the ratio that shows the performance comparison between the operational costs incurred by the bank and operating income that the bank can generate. This operating income ratio is usually called the efficiency ratio, which is used to measure bank management's ability to control operational costs incurred against operating income(Muhammad, 2014).

\section{Financing Deposit Ratio}

The financing to deposit ratio (FDR) is an essential factor for the sustainability of a banking company. This ratio is used to measure the number of time deposits, demand deposits, savings, and others used to fulfill applications for loans from customers. Sources of funds that come from the wider community it is third-party funds. These funds are obtained in various ways savings type offer. Funds from these third parties are funds entrusted by the broader community to banks in demand deposits, time deposits, savings, or equivalent(Kasmir, 2015). 


\section{Non Performing Financing}

NPF is a ratio of financing problems or non-performing financing to the total of financing. In carrying out fundraising activities that cannot be separated from various risks, deep earn income (Muhammad, 2014).

\section{RESEARCH METHOD}

In this study, researchers used quantitative research with an approach associative. Quantitative research is research conducted by collecting data in the form of numbers, and the data is processed and analyzed to obtain information science behind the numbers(Martono, 2017). This paper uses three variables: the independent variable (independent), the dependent variable (dependent), and the intervening variable. The variables are as follows: The independent variable (independent) In this study, researchers used two independent variables; Operational Costs and Operational Income and Financing To Deposit Ratio. The dependent variable; Return On Asset as a variable bound. Intervening Variables; Non-Performing Financing as a variable intervening. This research was conducted on the quarterly financial reports of Bank Syariah Indonesia within eight years (Quarter I 2013 - Quarter IV 2020). The population in this study is the Indonesian Islamic Bank in Indonesia. Sample selection using a purposive sampling method. In testing and analyzing the quarterly financial reports of Bank Syariah Indonesia 2013- 2020. Source of data from the website of Bank Syariah Indonesia.

\section{RESULTS AND DISCUSSION}

Descriptive Testing Results

Table 2. Descriptive Statistics Test Results

\begin{tabular}{lccccc}
\hline & N & Min & Max & Mean & Std. Dev \\
\hline $\begin{array}{l}\text { Operating costs and } \\
\text { Income Operational }\end{array}$ & 32 & 80.80 & 99.84 & 92.8434 & 4.06063 \\
\hline $\begin{array}{l}\text { Financing To Deposit } \\
\text { Ratio }\end{array}$ & 32 & 68.10 & 105.61 & 86.8469 & 10.32625 \\
\hline Return On Asset & 32 & 0.14 & 1.34 & 0.6847 & 0.30940 \\
\hline $\begin{array}{l}\text { Non Performing } \\
\text { Financing }\end{array}$ & 32 & 2.35 & 6.73 & 4.5169 & 1.01350 \\
\hline $\begin{array}{l}\text { Valid N (listwise) } \\
\text { Source: Secondary data processed in 2021. }\end{array}$ & 32 & & & \\
\hline
\end{tabular}


Based on the descriptive statistical data table 2, it can be seen as follows:

a. Operating Costs and Operating income

It can be seen that the minimum value of BOPO is 80.80 . In comparison, the maximum value or the most significant value is 99.84 . It shows that magnitude BOPO 80.80 - 99.84, average value 92.8434, the standard deviation of 4.06063. The mean values are more significant than the standard deviation, which is 92.8434> 4.06063 , which means a good distribution of BOPO values.

b. Financing To Deposit Ratio

It can be seen that the minimum or smallest value of the FDR is 68.10. in comparison, the maximum value or the most excellent value is 105.61. It shows the magnitude of FDR ranged from 68.10 - 105.61 and an average value of 86.8469 at a standard deviation of 10.32625 . The mean value that is greater than the standard deviation is $86.8469>10.32625$. It can be interpreted that the distribution of the FDR value is good.

c. Return On Asset

It can be seen that the minimum value or the smallest value of ROA is 0.14 . While the maximum value or the most significant value is 1.34 . It shows that amount of ROA ranged from $0.14-1.34$, and the value of the average 0.6847 at the standard deviation of 0.30940 . The mean value, which is smaller than the standard deviation, namely 0.6847>0.30940, means good ROA distribution.

\section{Multiple Linear Regression Model Equation I (BOPO, FDR and NPF Against} ROA)

$$
\begin{aligned}
& \dot{Y}=\beta 0+\beta 1 \mathrm{X} 1+\beta 2 \mathrm{X} 2+\beta 3 \mathrm{Z}+\mathrm{e} \\
& \dot{Y}=4,381-0.034 \mathrm{X} 1-0.006 \mathrm{X} 2-0.014 \mathrm{Z}
\end{aligned}
$$

Table 3. Multiple Linear Regression Test Results Equation I

\begin{tabular}{cc}
\hline Independent Variable & Coefficient (B) \\
\hline (Constanta) & 4.381 \\
\hline $\mathrm{X} 1$ & -0.034 \\
\hline $\mathrm{X} 2$ & -0.006 \\
\hline $\mathrm{Z}$ & -0.014 \\
\hline
\end{tabular}

Source: Secondary data processed in 2021 
Based on the table 3, it can be concluded that:

a. The constant is 4.381 without being influenced by other variables-Return On Asset of 4,381 .

b. The regression coefficient of -0.034 means that if the BOPO variable is increased by 1 unit, ROA will decrease by 0.034 , assuming the other variables are fixed.

c. The regression coefficient of -0.006 means that if the FDR is increased by 1 unit, ROA will decrease by 0.006 , assuming the other variables are fixed.

d. The regression coefficient of -0.014 means that if the NPF is increased by 1 unit, then ROA will decrease by 0.014 , assuming the other variables are fixed.

\section{Multiple Linear Regression Model Equation II (BOPO, FDR to NPF)}

$$
\begin{aligned}
& Z=\beta 0+\beta 1 X 1+\beta 2 X 2+\mathrm{e} \\
& Z=0.357+0.101 X 2-0.060 X 2
\end{aligned}
$$

Table 4. Multiple Linear Regression Test Results Equation II

\begin{tabular}{cc}
\hline Independent Variable & Coefficient (B) \\
\hline (Constanta) & 0.357 \\
\hline X1 & 0.101 \\
\hline X2 & -0.060 \\
\hline
\end{tabular}

Source: Secondary data processed in 2021.

Based on table 4 above, it can be concluded that:

a. A constant of 0.357 without being influenced by other variables NPF of 0.357 .

b. The BOPO regression coefficient is 0.101 , which means that if the OEOI variable is increased by 1 unit, then the NPF will also increase by 0.101 , assuming other variables permanent.

c. The FDR regression coefficient of -0.060 means that if the FDR is increased by 1 unit, then the NPF will decrease by 0.060 , assuming that the other variables are fixed.

\section{Analysis of Line ( Path Analysis )}

\section{Equation 1:}

The direct effect of $\mathrm{X} 1$ on $\mathrm{Y}=-0.444$

The indirect effect of $\mathrm{X} 1$ to $\mathrm{Z}$ to $\mathrm{Y}=0.403 \times(-0.047)=-0.018941$

Total influence $(\mathrm{X} 1$ to $\mathrm{Y}$ correlation $) \quad=-0.444+(-.018941)=-0.462941$ 


\section{Equation 2:}

The direct effect of $\mathrm{X} 2$ on $\mathrm{Y}=-0.118$

The indirect effect of $\mathrm{X} 2$ to $\mathrm{Z}$ to $\mathrm{Y}=-0.609 \times(-0.047)=0.028623$

The indirect effect of $\mathrm{X} 2$ to $\mathrm{Z}$ to $\mathrm{Y}=-0.118+(0.028623)=-0.159377$

Table 5. Path Analysis Test Results

\begin{tabular}{cccc}
\hline \multirow{2}{*}{ Analysis results } & \multicolumn{3}{c}{ Contribution } \\
\cline { 2 - 4 } & Direct & Indirect & Total \\
\hline X1 against $Y$ & -0.444 & & -0.444 \\
\hline X2 against $Y$ & -0.188 & & -0.188 \\
\hline Z against $Y$ & -0.047 & & -0.047 \\
\hline X1 againts $Z$ & 0.403 & & 0.403 \\
\hline X2 againts $Z$ & -0.609 & & -0.609 \\
\hline X1 against $Y$ & & $0,403^{*}-0.047=$ & $-0.444-0.018941=$ \\
Through Z & & -0.018941 & -0.462941 \\
\hline X2 against $Y$ & & $-0.609^{*}-0.047$ & $-0.188+0.028623=$ \\
through $Z$ & & $=0.028623$ & -0.159377
\end{tabular}

Source: Secondary data processed in 2021.

With the results of the path analysis above, it can be concluded that between others as follows:

1. Effect of OEOI on ROA with NPF as the Intervening Variable

Based on the results of table 5, regression coefficient value to find out whether NPF variable can mediate OEOI to the level of net income in a way multiplying the coefficient value between BOPO and NPF with the value of the NPF coefficient against ROA. The result of multiplying the coefficient is compared with the value of the BOPO coefficient on ROA.

a. The regression coefficient of BOPO costs on net ROA is -0.444 .

b. The regression coefficient of OEOI costs to NPF is 0.403 .

c. The regression coefficient of ROA on NPF is -0.047 .

d. The result of the indirect multiplication of the variable BOPO (X1) to ROA (Y) through

e. $\operatorname{NPF}(Z)(-0.403 X-0.047)=-0.018941$.

Based on the calculation of the direct and indirect effect of BOPO and NPF as an intermediate variable on ROA, which shows a compensation (calculation) which 
leads to low direct influence. Where is more ROA both using the indirect effect of 0.018941 through the intermediary factor NPF, while the direct effect of -0.444 on ROA? it means that BOPO can increase ROA through the intermediate factor NPF or using no direct effect.

2. Effect of FDR on ROA with NPF as the Intervening Variable

Based on table 5, regression coefficient value results to determine whether the NPF variable can mediate FDR to ROA by multiplying the value of the coefficient between FDR and NPF with the value of the NPF coefficient on ROA. The result of the multiplication of the coefficient is compared with the value of the FDR coefficient against ROA.

a. The regression coefficient of FDR on ROA is -0.188 .

b. The regression coefficient for FDR on NPF is -0.609 .

c. The regression coefficient of ROA on NPF is -0.047 .

d. The result of indirect multiplication of the variable FDR (X2) on ROA t (Y) through

e. $\operatorname{NPF}(Z)(-0.609 X-0.047)=0.028623$

Based on the calculation of the direct and indirect effect of FDR and NPF as an intermediate variable on ROA, which shows a compensation (calculation) which leads to low direct influence. Where is more ROA either using the indirect effect of 0.028623 through the intermediary factor NPF, while the direct effect is -0.188 on ROA? It means that FDR can increase ROA through the intermediate factor NPF or using no direct effect.

\section{DISCUSSION}

\section{Effect of Operational Costs and Operating Income on Return On Assets}

Based on the results of the partial test (t-test), the t-count was -2.721>2.037 from the $\mathrm{t}$ table, so that $\mathrm{H}$ a is accepted and a significance value is obtained of 0.006 $<0.05$, then $\mathrm{H}$ a is accepted, meaning that Operational Costs and Operating Income have a significant effect against Non-Performing Financing. Based on the results of hypothesis testing, it can be concluded that Operational Costs and Operational Income affect Return On Asset and show the regression coefficient of the Operational Costs variable and Operating income has a negative sign, which means Operating Costs and Income Operations have a significant adverse effect on Return On Assets. 44 
Due to the value of Operational Costs and Operating Income Bank Syariah Indonesia is still high with an average of $89 \%$, yes seen in several quarters with a value of more than $90 \%$. As a result, the bank's performance in Sharia Indonesia is less efficient. The operational efficiency will be issued yields more significant profits. The solution is so that the Bank's Operational Costs and Operating Income are efficient Sharia Indonesia must pay attention to its operational efficiency concerning expenses incurred with the income received. Operational Costs and Low operating income will significantly affect the size of the level advantages of Islamic banks to improve the quality of return on assets, save costs, and further increase the income so that the profit is earned getting higher.

\section{Effect of Financing To Deposit Ratio on Return On Assets}

Based on the results of the partial test (t-test), the t-count was $-0.584<2.037$ from the t table, so that $\mathrm{H} 0$ is accepted and a significance value of $0.564>0.05$ is obtained $\mathrm{H} \mathrm{O}$ is accepted, meaning that the Financing To Deposit Ratio has no significant effect on Return On Asset. Based on the results of the hypothesis, it can be concluded that the variable financing. To Deposit, Ratio does not affect Return On Asset and shows the amount. The regression coefficient of the Financing To Deposit Ratio variable is negative, meaning financing. To Deposit, Ratio has no significant adverse effect on Return On Asset. 45

This study found that the amount of financing did not influence the increase in return On assets. The Financing To Deposit Ratio in several quarters exceeds the maximum limit of $100 \%$. The high value of the Financing To Deposit Ratio at Islamic Bank Indonesia indicates that Bank Syariah Indonesia is less efficient in distribution financing. The solution is that Indonesian Sharia Banks must maintain the value of the Financing To Deposit Ratio at the safe limit set by Bank Indonesia.

\section{Effect of Non-Performing Financing Of Return On Assets}

Based on the results of the partial test (t-test), the results of $t$ count are minor than $\mathrm{t}$ table $-0.743<2.037$, so that $\mathrm{H} 0$ is accepted and a significance value of $0.463>$ 0.05 is obtained, then $\mathrm{H} 0$ is accepted, meaning that Non-Performing Financing has no significant effect against Return On Asset. Based on the results of the hypothesis, it states that the variable Non-Performing Financing does not affect Return On Assets and 
shows. The regression coefficient of the Non-Performing Financing variable is negative, meaning that it is Non-Performing Financing does not have a significant adverse effect on Return On Assets. Based on the results of this study, Non-Performing Financing does not affect because the value of Non-Performing Financing in Indonesian Islamic Banks in the analysis financial statement data has a high value within the existing limits determined by Bank Indonesia. In solution, Bank Syariah Indonesia must limit the value. Non Performing Financing to improve the quality of financing.

\section{The Influence of Operational Costs and Operating Income on Non-Performing Financing}

Based on the results of the partial test (t-test), the results of $t$ count is more significant than table 2.943>2.037, so that $\mathrm{H}$ a is accepted and the significance value is $0.006<0.05$, then $\mathrm{H}$ a is accepted, meaning that Operational Costs and Operating Income affect significantly to Non-Performing Financing. The hypothesis states that Operational Costs and Operational Income affect Non-Performing Financing and show the regression coefficient's amount. Variable Operating Costs and Operating Income are positive, meaning Costs Operations and Operating income affect Non-Performing Financing significantly. Based on this research, Operational and Operating Income have a significant positive effect on Non-Performing Financing. Judging from the analysis of the report date finance, the value of Operating Costs and Operating Income experienced a decrease, and at that time, the value of Non-Performing Financing also experienced a drop. The solution is Bank Syariah Indonesia must have high income with low operating costs. It can reduce the ratio of Operating Costs and Operating Income so that Bank Syariah Indonesia is healthy. That is, the occurrence of problematic financing will occur below.

\section{Effect of Financing to Deposit Ratio Of Non-Performing Financing}

Based on the results of the partial test (t-test), the results of $t$ count is more significant than the $\mathrm{t}$ table of $-4.749>2.037$, so that $\mathrm{H}$ a is accepted and the significance value is $0,000<0.05$, then $\mathrm{H}$ a is accepted, meaning that the Financing to Deposit Ratio has a significant effect on Non-Performing Financing. Based on the hypothesis's results, the Financing to Deposit Ratio significantly affects Non-Performing Financing. It shows the regression coefficient of the Financing to Deposit Ratio variable is negative, which 
means that the Financing to Deposit Ratio has a significant negative effect on NonPerforming Financing. Based on this research, the Financing to Deposit Ratio has a significant negative effect against Non-Performing Financing. Due to the increased precautionary principle implemented by sharia banks. The solution is that Indonesian Sharia Banks must use the number of funds in the banking sector to the maximum extent possible in channeling financing to decrease financing risk.

\section{The Influence of Operational Costs and Operating Income, Financing To Deposit Ratio and Non-Performing Financing to Return On Asset}

The hypothesis states that the Operational Cost variable and Operating Income, Financing to Deposit Ratio, and Non-Performing Financing together do not affect Return On Asset. Based on the F test obtained, The calculated F value is $2.692<2.946 \mathrm{~F}$ table and the significant value is $0.065>0.05$ so that $\mathrm{H} 0$ accepted and it can be concluded that the Operating Costs and Operating Income, Financing To Deposit Ratio and Non-Performing Financing are not together effected on Return On Asset. The results of the determination test show R2 amounting to 0.473 , which means the independent variable Operating Costs and Operating Income, Financing To Deposit Ratio and Non-Performing Financing affect Return On Asset was 47.3\%. In comparison, other factors outside the model influenced the remaining 52.7\%.

\section{The Influence of Operational Costs and Operating Income and Financing To Deposit Ratio to Non-Performing Financing}

Based on the results of the hypothesis, it states that Operating Costs and Income Operational and Financing To Deposit Ratio together affect Non-Performing Financing. Based on the F test, the calculated F value is more than $24.842>3.327$ from the F table and a significant value of $0.000<0.05$ so that $\mathrm{H}$ a is accepted, and it can be concluded that Operational Costs and Operating Income and Financing To Deposit Ratio together affects Non-Performing Financing. Test results determination shows R2 amounting to 0.768, which means Operating Costs and Income Operations and Financing To Deposit Ratio affect Non-Performing Financing $76.8 \%$ while other factors outside the model influence the remaining $23.2 \%$. Based on the financial report, the value of Operational Costs and Operating Income has decreased, and the value of Non-Performing Financing decreased. The Value of the Financing To Deposit Ratio increases, and at that time, the 
value of Non-Performing Financing experienced a drop. In other words, the lower the Operating Costs and Income Operational and hence Non-Performing Financing (more problematic financing low). Furthermore, the higher the Financing To Deposit Ratio, the Non-Performing Financing (financing problems are getting lower). The solution is Bank Syariah Indonesia must have a high income with fees low operational. It can reduce the ratio of Operating Costs and Income Operational so that Indonesian Sharia Bank is in a healthy position, meaning that it happens that problematic financing will below. Indonesian Sharia Bank must use the number of funds in the banking sector to the maximum extent possible in channeling financing so that the risk of financing is reduced.

The Effect of Operational Costs and Operating Income on Return On Asset with Non-Performing Financing as an Intervening variable

Based on Table 5 that Non-Performing Financing can mediate between Operational Costs and Operating Income with Return On Assets. It is proven that the indirect effect is greater than the direct effect. The thing this is indicated by the value of the multiplication of the regression coefficient of Operating Costs and Income Operations against NonPerforming Financing (0.403) with NonPerforming Financing to the Return On Asset (-0.047) is -0.018941 greater than the coefficient value regression of Operational Costs and Operating Income to Return On Assets (-0.444). It can be seen that this study has a significant effect on Operational Costs and Operating Income to Non-Performing Financing and precisely Costs Operational and Operating Income to Return On Assets indirectly significant effect.

\section{Effect of Financing To Deposit Ratio Against Return On Assets with Non- Performing Financing as an Intervening variable}

Financing To Deposit Ratio with Return On Asset. It was proved that the influence was not a direct effect is more significant than direct influence. It is indicated by the multiplication value of the regression coefficient of Financing To Deposit Ratio to Non-Performing Financing $(-0,609)$ with Non-Performing Financing to Return On Assets $(-0,047)$ is $(0.028623)$ more significant than the regression coefficient value of Financing To Deposit Ratio to Return On Assets (-0,188). It can be seen that this study has a significant effect on Financing To Deposit Ratio to Return On Assets through 
Non-Performing Financing and Financing To Deposit Ratio to Return On Asset has no direct effect significant.

\section{CONCLUSION}

1. Operational Costs and Operating Income have a significant adverse effect on Return On Asset at Bank Syariah Indonesia.

2. Financing To Deposit Ratio has no significant adverse effect on Return On Assets in Indonesian Sharia Bank.

3. Non-Performing financing has no significant adverse effect on Return On Asset in Indonesian Sharia Bank.

4. Operational Costs and Operating Income have a significant positive effect on Non-Performing Financing at Indonesian Sharia Bank.

5. Financing To Deposit Ratio has a significant negative effect on Non-Performing Financing at Bank Syariah Indonesia.

6. Operational Costs and Operating Income, Financing To Deposit Ratio and NonPerforming Financing together does not affect Return On Asset in Indonesian Sharia Bank.

7. Operational Costs and Operating Income and Financing To Deposit Ratio together have the same effect on Non-Performing Financing.

8. Non Performing Financing can mediate Operating Costs and Income Operations on Non-Performing Financing at Indonesian Sharia Banks.

9. Non Performing Financing can mediate between Financing To Deposit Ratio against Return On Asset at Bank Syariah Indonesia.

\section{REFERENCE}

Armereo, C. (2015). ANALISIS FAKTOR - FAKTOR YANG MEMPENGARUHI PROFITABILITAS BANK SYARIAH YANG TERDAFTAR DI BURSA EFEK INDONESIA INDONESIA. Jurnal Ilmiah Ekonomi Global Masa Kini, $6(2), 48-56$.

Dendawijaya, L. (2001). Manajemen Perbankan. Jakarta: Ghalia Indonesia.

Dendawijaya, L. (2005). Manajemen Perbankan. Bogor: Ghalia Indonesia.

Hariyani, Iswi. (2010). Restrukturisasi dan penghapusan kredit macet. Jakarta: Alex Media Komputindo.

Kasmir. (2015). Analisis Laporan Keuangan. Jakarta: Rajawali Pres.

Mahardian, P. (2008). ANALISIS PENGARUH RASIO CAR, BOPO,NPL, NIM DAN LDR TERHADAP KINERJAKEUANGAN PERBANKAN(STUDI KASUS 
PERUSAHAAN PERBANKAN YANGTERCATAT DI BEJ PERIODE JUNI 2002

- JUNI 2007). Universitas Diponegoro, Semarang.

Martono, N. (2017). Metode penelitian kuantitatif: Analisis Isi dan Analisis Data

Sekunder. Jakarta: Raja Grafindo Persada.

Muhammad. (2014). Manajemen Dana Bank Syariah. Jakarta: Raja Grafindo Persada.

Parenrengi, S., \& Hendratni, T. W. (2018). Pengaruh dana pihak ketiga, kecukupan

modal dan penyaluran kredit terhadap profitabilitas bank. 1(1), 9-18.

https://doi.org/10.36407/jmsab.v1i1.15

Rosidah, E. (2017). PENGARUH FINANCING TO DEPOSIT RATIO TERHADAP NON PERFORMING FINANCING PERBANKAN SYARIAH DI

INDONESIA. JURNAL AKUNTANSI, 12(2), 127-134.

Septiani, R., \& Lestari, P. V. (2016). PENGARUH NPL DAN LDR TERHADAP PROFITABILITAS DENGAN CAR SEBAGAI VARIABEL MEDIASI PADA PT BPR PASARRAYA KUTA. E-Jurnal Manajemen, 5(1), 293-324.

Sugiono, A., \& Untung, E. (2016). Analisis Laporan Keuangan. Jakarta: PT. Grasindo.

Tahliani, H. (2020). Tantangan Perbankan Syariah dalam Menghadapi Pandemi Covid19. Jurnal Madani Syari'ah, 3(2), 92-113.

Tambunan, A. P. (2007). Menilai Harga Wajar saham. Jakarta: Elex Media Komputindo.

Wangsawidjaja Z, A. (2012). Pembiayaan bank syariah. Ja: Gramedia Pustaka Utama. 